\title{
Esculent coating of spider silk enhanced the preservation and shelf life of apricot
}

\author{
H. M. Tahir*a (D), N. Pervez (D) J. Nadeem $^{a}$ (D), A. A. Khan ${ }^{b *}$ (D) and Z. Hassan

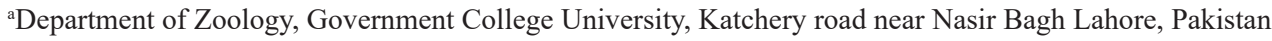 \\ ${ }^{b}$ College of Agriculture, Bahauddin Zakariya University, Bahadur Campus Layyah, Pakistan \\ *e-mail: drkupchani@bzu.edu.pk; hafiztahirpk1@yahoo.com
}

Received: April 8, 2018 - Accepted: June 18, 2018 - Distributed: February 28, 2020

(With 6 figures)

\begin{abstract}
According to the Food and Agriculture Organization (FAO), roughly one-third of the total food produced is lost globally. The major cause of this wastage is the perishability of fruits and vegetables. Therefore, researchers have endeavored to develop an effective preservation technique. Our study explored the potential application of spider silk as an odourless and edible preservative coating for fruits. The spider silk was collected from spiders reared in the laboratory, following by degumming and dissolution to formulate the silk solution. For this study, apricots were selected as the model fruit. The apricots were dip coated with the formulated silk solution and allowed to dry. In order to enhance the beta sheet content of the silk coating, the fruits were exposed to water annealing for varying intervals of time under vacuum condition. The effect of silk coating and water annealing time period on preservation of fruits was then evaluated morphologically and gravimetrically. The results showed that the fruits, which were used as control, exhibited a greater degree of water loss and suffered from fungal attack. In contrast, the silk coated fruits showed less water loss and were protected from fungal attack. Therefore, the study provides compelling evidence regarding the application of spider silk as a preservative coating.
\end{abstract}

Keywords: spider silk, fruits, edible covering, perishable fruits, water annealing.

\section{A cobertura escamada de seda de aranha aumentou a preservação e a vida útil do damasco}

\section{Resumo}

Segundo a Organização para Alimentação e Agricultura (FAO), cerca de um terço do total de alimentos produzidos é perdido globalmente. A principal causa deste desperdício é a perecibilidade das frutas e legumes. Portanto, os pesquisadores têm se esforçado para desenvolver uma técnica de preservação eficaz. Nosso estudo explorou a potencial aplicação de seda de aranha como um revestimento conservante inodoro e comestível para frutas. A seda da aranha foi coletada de aranhas criadas em laboratório, seguindo-se a degomagem e dissolução para formular a solução de seda. Para este estudo, os damascos foram selecionados como fruto modelo. Os damascos foram revestidos por imersão com a solução de seda formulada e deixados secar. A fim de aumentar o teor de folhas beta do revestimento de seda, os frutos foram expostos a recozimento de água durante vários intervalos de tempo sob condições de vácuo. O efeito do tempo de recobrimento de seda e recozimento de água na preservação de frutos foi então avaliado morfologicamente e gravimetricamente. Os resultados mostraram que os frutos, utilizados como controle, apresentaram maior grau de perda de água e sofreram ataque fúngico. Em contraste, os frutos revestidos de seda mostraram menos perda de água e foram protegidos contra ataques fúngicos. Portanto, o estudo fornece evidências convincentes sobre a aplicação de seda de aranha como um revestimento conservante.

Palavras-chave: seda de aranha, frutos, cobertura comestível, frutos perecíveis, recozimento de água.

\section{Introduction}

Fruits are an excellent source of energy and provide important nutrients, vitamins and minerals to the body. Their nutritional value is highest when they are fresh (Liu, 2003). Most fruits have very short shelf life (Barrett and Lloyd, 2012) and their preservation is a challenging task all over the world. Almost one-third of the fruits and vegetables are lost annually (FAO, 2011). Therefore, food wastage is a major hindrance in the economic development of a country (Droby, 2005; Zhu, 2006). Most of the fruit spoilage is due to microbial growth which secretes cell 
wall degrading enzymes (Al-Hindi et al., 2011). Thus, keeping in mind all these problems and the increasing market demand of fruits, an appropriate method of fruit preservation is a need of the hour.

To date, various methods have been used for the preservation of fruits such as heating, drying, cryopreservation, exposure to synthetic chemical fungicides and the use of additives like salt and sugar (Ahmed et al., 2016; Marelli et al., 2016). However, these preservation methods fail to ensure the freshness and natural taste of the fruits. Moreover, they can also lead to the overall loss of original nutrient contents (Barrett and Lloyd, 2012). Currently, a novel and more advanced technique is being explored, which involves coating fruits in an odorless and edible silk fibroin. This can keep fruits fresh for more than a week at ordinary conditions (Marelli et al., 2016; Vargas et al., 2008).

Silk protein coating actually reduces the fruit's cell respiration rate by balancing the natural flow of oxygen and carbon dioxide and by reducing the rate of water transpiration in fruit, thus intrinsically slowing the decomposition process (Marelli et al., 2016). Spiders store their extra food in their silk which is preserved for months and even years without being attacked by fungus or bacteria (Eberhard et al., 2006). This preservation property of spider silk is due to the presence of antimicrobial compounds that resides within the spider silk (Roozbahani et al., 2014). Spider silk contains a protein known as "spidroin" which consists of amino acids like glycine, alanine and serine abundantly which protect it from drying out (Altman et al., 2003; Saravanan, 2006).

Furthermore, phospholipids hydrate and potassium nitrate present in spider silk prevent the growth of fungi and bacteria on the silk (Chakraborty and Das, 2009; Tahir et al., 2015). Silk fibroin is exclusive in the sense that it is environment friendly and it makes substances sustainable, stable and protected (Harris et al., 2016). When the silk is in solution form it allows delicate food to last longer which is because of the formation of beta-sheets (Huemmerich et al., 2004). In particular, increased beta-sheet content corresponds to a reduction in oxygen diffusion through the thin coating of silk fibroin (Marelli et al., 2016). The silk fibroin has all the properties which can overcome such problems. In addition, the coating is ultra-thin, durable and odorless which will have no effect on the texture and natural taste of the fruit (Marelli et al., 2016).

The present study was designed to evaluate the potential of silk harvested from Argiope trifasciata (Araneae, Araneidae) spider as a preservative coating for perishable fruits. This species is a common orb-weaving spider found in agro-ecosystems of Punjab, Pakistan. Apricots were used as a model fruit in the study. Our hypothesis was that by coating the fruits with spider silk solution, the shelf life of fruits could be enhanced, up to 15 days at room temperature. Thereby allowing them to be safely transported to distant markets, especially foreign countries.

\section{Materials and Methods}

\subsection{Spider collection methods}

Spiders, Argiope trifasciata (Araneae, Araneidae), were collected from different areas of Punjab such as Changa Manga (31.20008N/73.95008E), Gajjumatta, main Ferozpur road, Lahore (31.37398N/74.36758E) and agricultural fields of University of the Punjab, Lahore $(31.4790 \mathrm{~N} / 74.2662 \mathrm{E})$. It is an orb-weaving spider which is abundantly present in the study area.

The following methods were employed to collect spiders:

\subsubsection{Visual search}

Collection of most of the spiders was done by direct hand picking. But for those spiders which were out of approach, a metallic wire was modified to form a loop in the anterior side and a long handle extending backward. A plastic disposable cup was fixed in the anterior loop of the metallic wire. Using this modified instrument, spiders were easily captured by forwarding the cup towards the spider and gently picking it up.

\subsubsection{Hand Net method}

An insect net was used to collect the spiders from vegetation. The net was extended to the area where the species were seen and after picking it was gently dragged. Spiders were stuck in the mesh net, from where they were collected and transferred to the falcon tubes. Openings of the tubes were covered with mesh cloth tight with rubber bands for ventilation.

\subsection{Rearing and feeding}

For rearing the spiders, special wooden boxes were designed, which were open from two sides to enable the entrance of light. The opened sides were covered with thick polythene sheet to prevent the escape of spiders. Moreover, to save the spiders from dying of suffocation, a small hole was cut in the sheet and covered with a porous piece of cloth. Sixteen hooks (four on each side) were fixed inside the box and connected with a fine thread to provide the spider with anchoring points so that it may form the web with ease.

Common house flies, Musca domestica, were fed to spiders twice a week. An insect net was used to capture the flies from a butcher's shop. Before feeding, the flies were kept in freezer for 2 minutes to stun for a short time in order to easily shift them to the falcon tubes.

\subsection{Silk collection}

For the collection of silk, a sterilized glass rod was used. One day after the release of spiders into the box, the web was wrapped around the rod and spiders were shifted to the falcon tube. The rod along the silk was kept in an air tight jar. The jar was then placed under UV light in a safety cabinet for 15 minutes to kill any microbial contaminants. The frequency of silk collection varied depending upon the feeding pattern and availability of rearing boxes. Egg sacs were also obtained from some spiders. The eggs were removed and the egg silk was stored in a separate airtight jar. 


\subsection{Degumming of silk}

The collected silk was very sticky in nature. Therefore, before dissolution, the silk was degummed according to the process outlined by Kim et al. (2003). Although freshly collected, the silk was washed twice with distilled water to ensure that it was free of contamination. The silk was then degummed twice by treating it with $0.5 \%$ solution of sodium bicarbonate $\left(\mathrm{NaHCO}_{3}\right)$ at $100{ }^{\circ} \mathrm{C}$ for 30 minutes. The degummed silk was then air dried and kept for dissolution.

\subsection{Dissolving Degummed silk}

For dissolving spider silk, two solutions were prepared. The first solution was of Calcium chloride ethanol and water $\left(\mathrm{CaCl}_{2}: \mathrm{C}_{2} \mathrm{H}_{5} \mathrm{OH}: \mathrm{H}_{2} \mathrm{O}\right)$ in the ratio of $1: 2: 8$ (Ajisawa, 1998). The other solution was of urea which was prepared by dissolving $48 \mathrm{~g}$ of urea in $100 \mathrm{ml}$ water. Then the two solutions were mixed and $50 \mathrm{ml}$ of the final solution was taken in a beaker. $0.08 \mathrm{~g}$ silk was dissolved in $50 \mathrm{ml}$ of dissolving solution with constant stirring at $70{ }^{\circ} \mathrm{C}$ for 2 hours.

After dissolution, the silk solution was dialyzed for three days with distilled water using dialysis membrane to remove the chemical residues. The removal of chemicals was confirmed by the neutral $\mathrm{pH}$ of the solution. To enhance the concentration of silk solution, centrifugation was done at speed of 5000rpm for 20 minutes. The final volume of solution left after all the processing was $15 \mathrm{ml}$, which was used for coating the fruits.

\subsection{Fruits dip coating}

Freshly picked apricots were taken and weighed by using a digital balance. A steel tray was covered with Aluminum foil and fruits were arranged on it. Then their weight was labeled under each apricot and photographs were taken. The other apricots were dipped well in the silk solution and dried properly. One group was considered as control and apricots of this group were not treated with the silk solution. The silk coated apricots were then treated with water annealing post-processing for different time intervals.

\subsection{Coating crystallization}

Water annealing was used as post-process to modulate the relative content of beta sheets in silk protein. The longer is the exposure to water vapors, the higher is the beta-sheet content of protein (Marelli et al., 2016). Exposure time was set to $0 \mathrm{~s}, 1$ hour, 2 hours, 4 hours and 5 hours. Silk coated fruits were exposed to water vapors under vacuum condition at $34{ }^{\circ} \mathrm{C}$ temperature. The set-up was self-designed in which a plastic tank was used. The tank was well sealed and a vacuum pump was attached at one side. At the center of the tank a mesh net was fixed, on which the fruits were adjusted. The tank was filled with $1000 \mathrm{ml}$ distill water and kept in water bath at adjusted temperature. A thermometer was inserted at one end to check the temperature. Then the fruits were kept for water annealing post treatment. One group was not treated with water annealing post-process in order to check the effect of silk coating without water annealing. The others groups were treated water annealing process and were taken out after 1 hour, 2 hours, 4 hours and 5 hours respectively. Then the treated fruits along with the control were kept in laboratory at $26^{\circ} \mathrm{C}$ temperature. The fruits were observed on regular basis and photographs were taken and weight was measured.

\subsection{Evaluation of freshness of fruits}

The effect of silk coating and water annealing time on freshness of fruits was evaluated morphologically and gravimetrically. Changes in the color and shape of fruits were evaluated through good photography. Gravimetric analysis of fruits as received and after treatment at days $1,3,7$ and 10 were evaluated with a standard weighing balance. The results of silk coated fruits were compared with the non-coated fruit i.e. control.

\subsection{Statistical analysis}

Normality of the data was assessed using KolmogorovSmirnov test. One-way analysis of variance followed by Tukey's test was used to compare the control and experimental groups. Results were considered significant if $\mathrm{p}$-values were less than 0.05 .

\section{Results}

\subsection{Morphological analysis}

The apricots which were treated with spider silk solution were comparatively fresher than untreated control apricots even on the $10^{\text {th }}$ day of treatment. On $1^{\text {st }}$ and $2^{\text {nd }}$ day, the apricots were fresh (Figure 1 and 2) but at day $3^{\text {rd }}$ a slight change was observed in the control group (Figure 3). At $4^{\text {th }}$ day, it was observed that the control fruit was perishing and it was very soft as compared to the silk treated fruits (Figure 4). At $7^{\text {th }}$ day, the control group was totally perished and massive fungal growth was observed (Figure 5). At $10^{\text {th }}$ day, the apricot without annealing was also perished (Figure 6). It was clearly observed that the longer the exposer time of water annealing the fresher was the fruit. In addition, the control group was totally perished and the fruits without water annealing were also perishing slowly.

\subsection{Gravimetric analysis}

The greatest weight loss $(17.39 \pm 0.34)$ was recorded in the control group at $10^{\text {th }}$ day $(17.39 \pm 0.34)$ as compare to the experimental groups. In contrast, the minimum weight lost (12.46 \pm 0.10$)$ was observed in the apricot which was exposed to water annealing for one hour. A considerable loss of weight was also observed in the group which was not treated with water annealing. There was statistically significant difference in the weight loss between control and experimental groups. The details of weight lost in all the groups in different days are provided in (Table 1). 


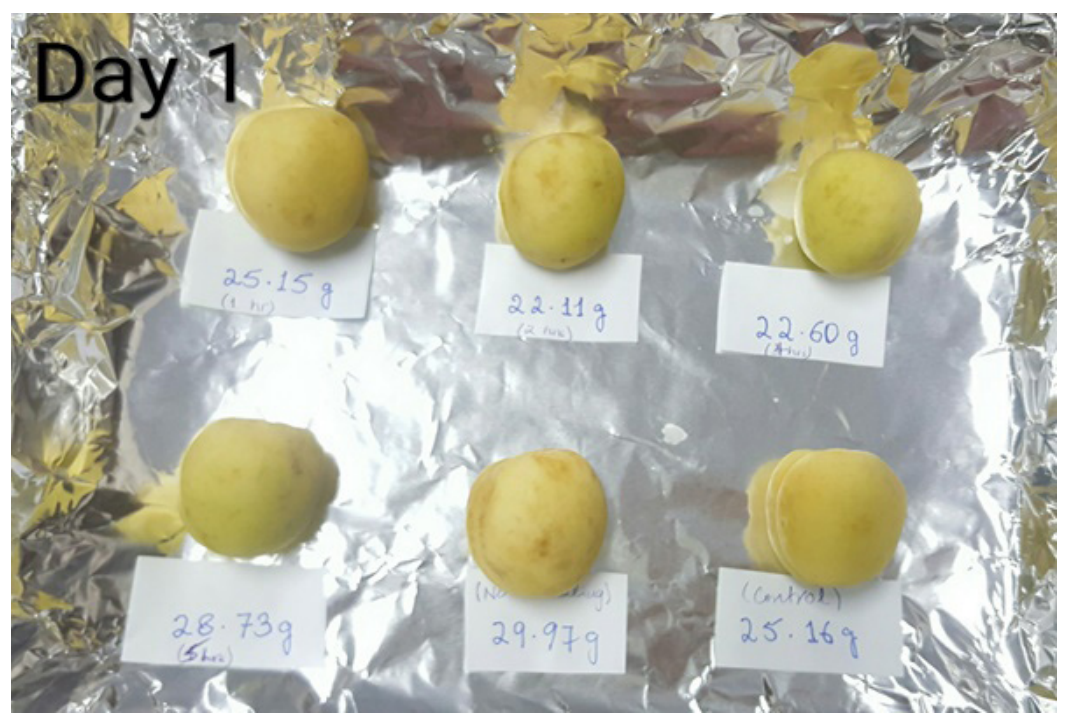

Figure 1. Morphological representation of Apricots at Day-1 after silk coating.

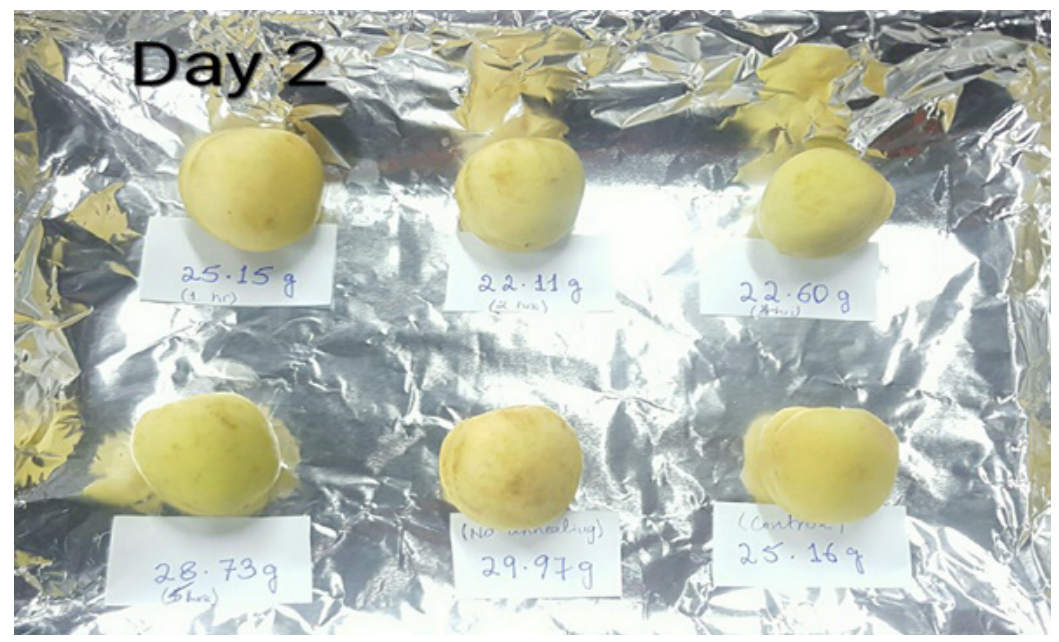

Figure 2. Morphological representation of Apricots at Day-2 after silk coating.

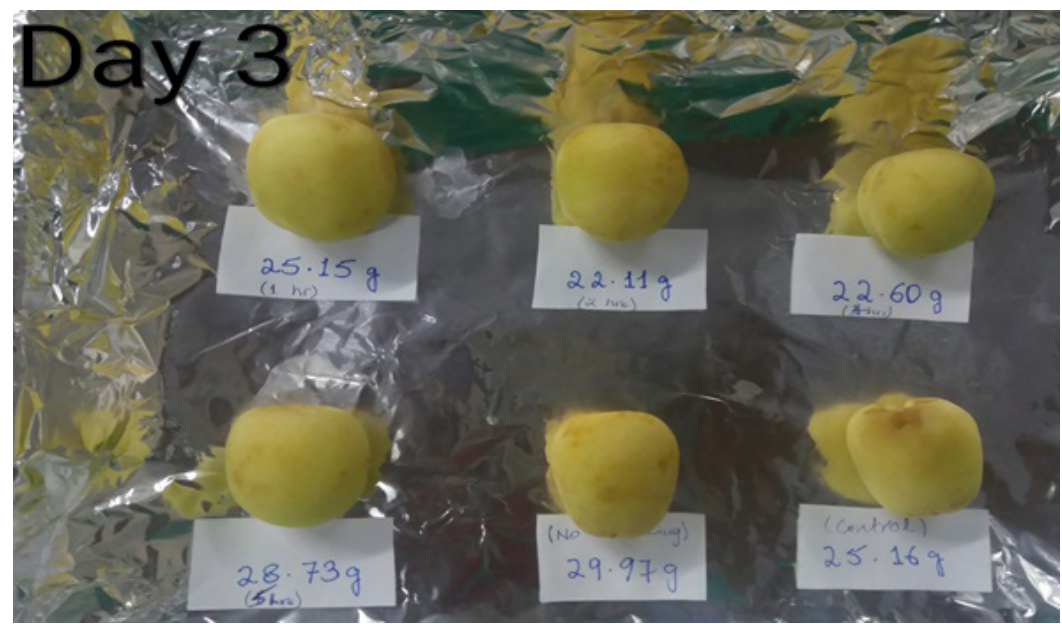

Figure 3. Morphological representation of Apricots at Day-3 after silk coating. 


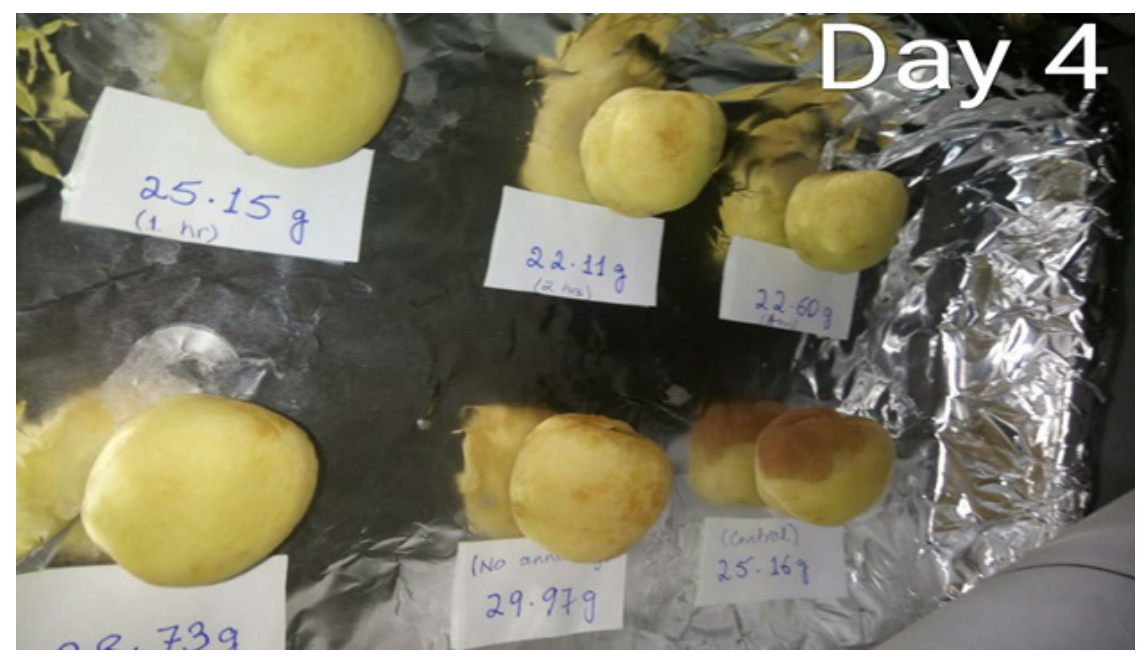

Figure 4. Morphological representation of Apricots at Day-4 after silk coating.

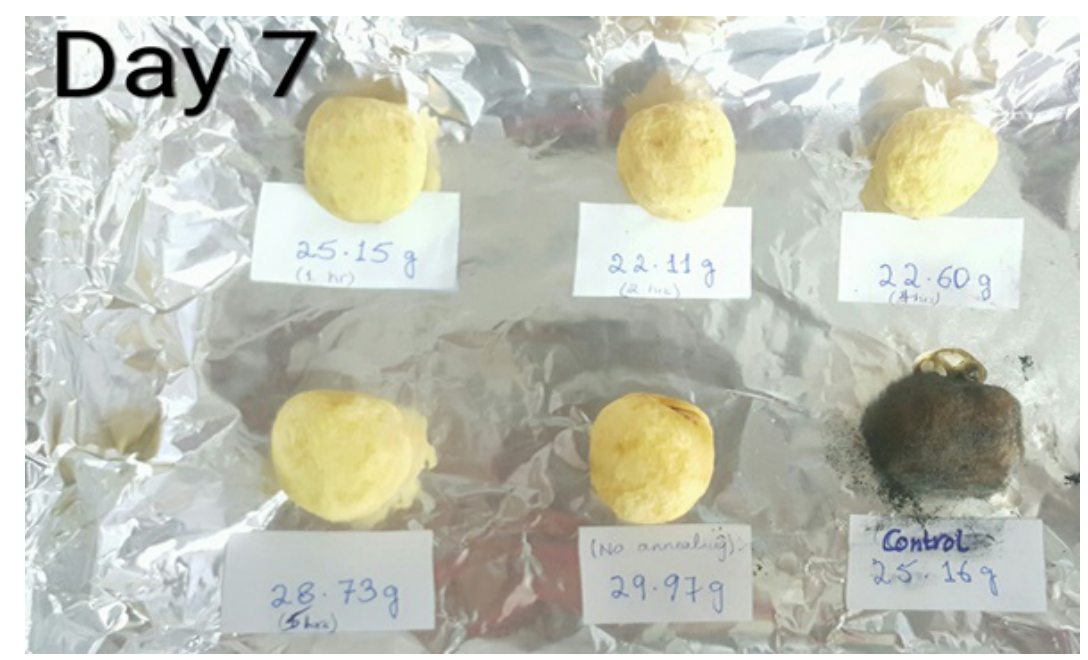

Figure 5. Morphological representation of Apricots at Day-7 after silk coating.

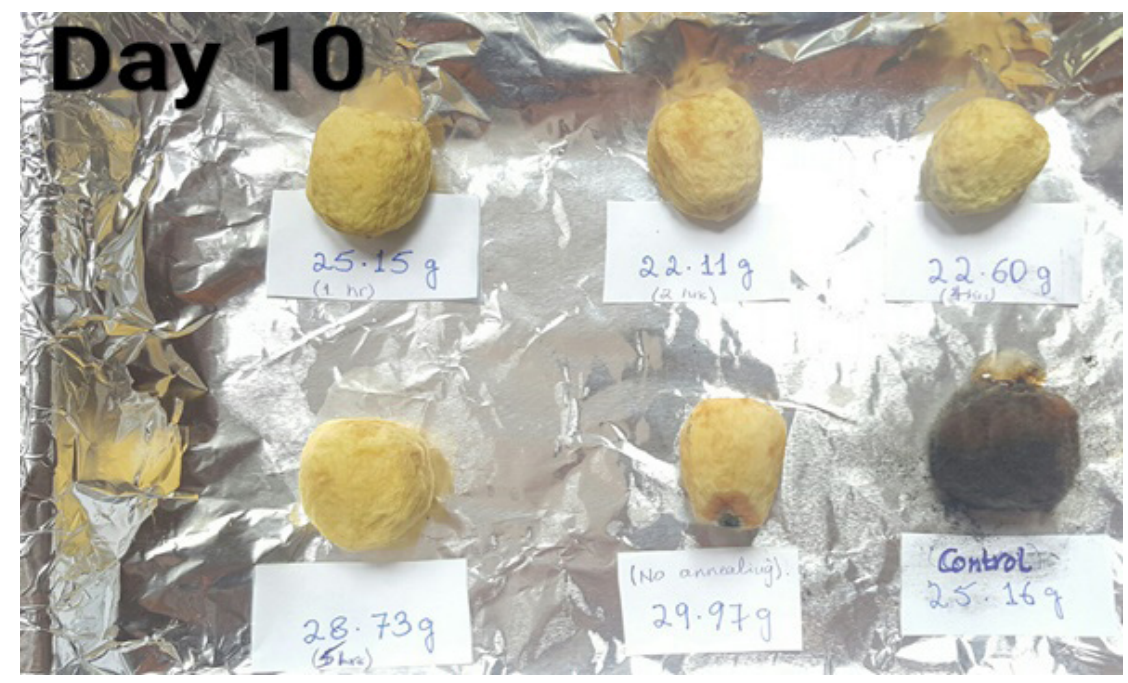

Figure 6. Morphological representation of Apricots at Day-10 after silk coating. 
Table 1. Loss of weight in control and experimental fruits at different days.

\begin{tabular}{cccc}
\hline $\begin{array}{c}\text { Water annealing time } \\
\text { (hours) }\end{array}$ & \multicolumn{3}{c}{ Weight lost at different days $(\mathbf{m g})$} \\
\cline { 2 - 4 } & $\mathbf{3}^{\text {rd }}$ day & $\mathbf{7}^{\text {th }}$ day & $\mathbf{1 0}^{\text {th }}$ day \\
\hline 0 & $5.59 \pm 0.32^{\text {ab }}$ & $11.85 \pm 0.25^{\mathbf{c}}$ & $14.23 \pm 0.30^{\mathbf{c}}$ \\
$1 \mathrm{hr}$ & $5.16 \pm 0.17^{\mathrm{a}}$ & $10.02 \pm 0.7^{\mathrm{a}}$ & $12.46 \pm 0.10^{\mathrm{a}}$ \\
$2 \mathrm{hrs}$ & $5.25 \pm 0.29^{\mathrm{ab}}$ & $10.78 \pm 0.19^{\mathbf{b}}$ & $13.09 \pm 0.12^{\mathrm{b}}$ \\
$4 \mathrm{hrs}$ & $5.89 \pm 0.20^{\mathbf{b c}}$ & $11.89 \pm 0.16^{\mathbf{c}}$ & $15.01 \pm 0.11^{\mathrm{d}}$ \\
$5 \mathrm{hrs}$ & $7.86 \pm 0.29^{\mathbf{c}}$ & $13.88 \pm 0.20^{\mathrm{e}}$ & $17.22 \pm 0.22^{\mathrm{e}}$ \\
Control & $5.68 \pm 0.29^{\mathrm{bc}}$ & $12.80 \pm 0.52^{\mathrm{d}}$ & $17.39 \pm 0.34^{\mathrm{e}}$ \\
D.F & 5,12 & 5,12 & 5,12 \\
F value & 40.49 & 76.80 & 254.78 \\
P-value & $<0.001$ & $<0.001$ & $<0.001$ \\
\hline
\end{tabular}

Note: The values in the column with different superscripts are statistically different. Superscripts are based on One-Way ANOVA followed by Tukey's test.

\section{Discussion}

The present study reports the potential application of spider silk as an edible coating for the preservation of fruits. It was hypothesized that the silk coating would allow the fruits to be preserved by protecting them from fungal attack and preventing water loss. Moreover, the study also investigated the effect of water annealing post-process on the preservation potential of the silk coating. The results obtained from the study indicate that the water loss was minimum in the silk coated fruits, while in contrast, the control group showed a significant degree of water loss (Table 1). The study focused on reducing the water loss from fruits because it is an essential indicator of their freshness. Furthermore, it was observed that the control group suffered from major fungal attack, whereas the silk treated group remained protected up to 10 days of observation (Figure 1-6). Thus, it provides compelling evidence regarding the antimicrobial potential of spider silk. The effect of water annealing was also evident from the obtained results. Due to an increase in beta-sheet content, the water annealed group exhibited less water loss when compared to the control and non-water annealed counterparts.

Marelli et al. (2016) used silk of Bombyx mori cocoons as an edible, preservative coating for fruit preservation. Extraction of silk fibroin was done by degumming process which involved boiling of silk cocoons in $0.02 \mathrm{M}$ sodium carbonate solution for 30 minutes. Silk fibroin was solubilized in 9.3M Lithium bromide for 4 hours in a $60{ }^{\circ} \mathrm{C}$ oven (Sah and Pramanik, 2010). The chaotropic salt was removed through dialysis against Milli-Q water for 72 hours. In our study, we used silk acquired from spider webs and egg sacs. For dissolution of spider silk we used a specially formulated solvent, which was cheaper, non-toxic and easily available. The solution was then dialyzed against distilled water for 72 hours in order to remove the processing chemicals to negate their effect.

The fruits used in our experiment were apricots which were preserved using spider silk. Water annealing was used as post-process to modulate the relative content of beat-sheets in silk fibroin coating. The longer the exposure period the greater is the beta-sheet content of silk protein (Hu et al., 2011; Marelli et al., 2016). In previous studies, silk coated fruits were exposed to water vapours under vacuum condition at $22{ }^{\circ} \mathrm{C}$ according to protocol developed by Hu et al. (2011). The exposure time was set to 0 s (No exposure), 1 hour, 6 hours and 12 hours. In our study, water annealing was done at $34{ }^{\circ} \mathrm{C}$ and exposure time was set to 0 s (No exposure), 1 hour, 2 hours, 4 hours and 5 hours.

After water annealing post-processing the apricots were kept at room temperature of $26{ }^{\circ} \mathrm{C}$. In the daily based observation, it was noticed that on fourth day the control group which was not coated with spider silk began to spoil. On seventh day, it was totally destroyed by a massive fungal attack. Hence, it was proved that in normal conditions apricot gets spoiled within four days and becomes unpalatable. However, spider silk enhanced the shelf life of apricots up to 14 days under normal conditions without refrigeration. Since the silk coating is odourless, tasteless and edible, the fruits can be eaten after preservation (Marelli et al., 2016). Therefore, it is concluded from the study that the silk coating, followed by water annealing, is an effective method to enhance the shelf life of apricots. However, effectiveness of this technique on other fruits and vegetables need to be evaluated.

\section{Acknowledgements}

We are grateful to Government College University Lahore for providing the necessary support to conduct this research.

\section{References}

AHMED, I., QAZI, I.M. and JAMAL, S., 2016. Developments in osmotic dehydration technique for the preservation of fruits and vegetables. Innovative Food Science \& Emerging Technologies, vol. 34, pp. 29-43. http://dx.doi.org/10.1016/j.ifset.2016.01.003.

AJISAWA, A., 1998. Dissolution of silk fibroin with calcium chloride/ethanol aqueous solution. The Journal of Sericultural Science of Japan, vol. 67, no. 2, pp. 91-94. 
AL-HINDI, R.R., AL-NAJADA, A.R. and MOHAMED, S.A., 2011. Isolation and identification of some fruit spoilage fungi: Screening of plant cell wall degrading enzymes. African Journal of Microbiological Research, vol. 5, no. 4, pp. 443-448.

ALtMAN, G.H., DIAZ, F., JAKUBA, C., CALABRO, T., HORAN, R.L., CHEN, J., LU, H., RICHMOND, J. and KAPLAN, D.L., 2003. Silk-based biomaterials. Biomaterials, vol. 24, no. 3, pp. 401-416. http://dx.doi.org/10.1016/S0142-9612(02)00353-8. PMid:12423595.

BARRETT, D.M. and LLOYD, B., 2012. Advanced preservation methods and nutrient retention in fruits and vegetables. Journal of the Science of Food and Agriculture, vol. 92, no. 1, pp. 7-22. http://dx.doi.org/10.1002/jsfa.4718. PMid:22102258.

CHAKRABORTY, D. and DAS, S., 2009. Antibacterial activities of cobweb protein. Clinical Microbiology and Infection, vol. 15, no. 4, pp. S626-S627.

DROBY, S., 2005. Improving quality and safety of fresh fruits and vegetables after harvest by the use of biocontrol agents and natural materials. International Symposium on Natural Preservatives in Food Systems, vol. 709, pp. 45-52.

EBERHARD, W.G., BARRANTES, G. and WENG, J.L., 2006. Tie them up tight: wrapping by Philoponella vicina spiders breaks, compresses and sometimes kills their prey. Naturwissenschaften, vol. 93, no. 5, pp. 251-254. http://dx.doi.org/10.1007/s00114-0060094-1. PMid:16544123.

FOOD AND AGRICULTURE ORGANISATION - FAO, 2011 [viewed 8 March 2016]. Global food losses and food waste [online]. Rome: FAO. Available from: http://www.fao.org/docrep/014/ mb060e/mb060e.pdf

HARRIS, T.I., GAZTAMBIDE, D.A., DAY, B.A., BROCK, C.L., RUBEN, A.L., JONES, J.A. and LEWIS, R.V., 2016. A Sticky Situation: An Investigation of Robust Aqueous-Based Recombinant Spider Silk Protein Coatings and Adhesives. Biomacromolecules, vol. 17, no. 11, pp. 3761-3772. http://dx.doi. org/10.1021/acs.biomac.6b01267. PMid:27704788.

HU, X., SHMELEV, K., SUN, L., GIL, E.S., PARK, S.H., CEBE, P. and KAPLAN, D.L., 2011. Regulation of silk material structure by temperature-controlled water vapor annealing. Biomacromolecules, vol. 12, no. 5, pp. 1686-1696. http://dx.doi. org/10.1021/bm200062a. PMid:21425769.

HUEMMERICH, D., HELSEN, C.W., QUEDZUWEIT, S., OSCHMANN, J., RUDOLPH, R. and SCHEIBEL, T., 2004. Primary structure elements of spider dragline silks and their contribution to protein solubility. Biochemistry, vol. 43, no. 42, pp. 13604-13612. http://dx.doi.org/10.1021/bi048983q. PMid:15491167.

KIM, S.H., NAM, Y.S., LEE, T.S. and PARK, W.H., 2003. Silk fibroin nanofiber. Electrospinning, properties, and structure. Polymer Journal, vol. 35, no. 2, pp. 185-190. http://dx.doi. org/10.1295/polymj.35.185.

LIU, R.H., 2003. Health benefits of fruit and vegetables are from additive and synergistic combinations of phytochemicals. The American Journal of Clinical Nutrition, vol. 78, no. 3, suppl., pp. 517S-520S. http://dx.doi.org/10.1093/ajen/78.3.517S. PMid:12936943.

MARELLI, B., BRENCKLE, M.A., KAPLAN, D.L. and OMENETTO, F.G., 2016. Silk fibroin as edible coating for perishable food preservation. Scientific Reports, vol. 6, no. 1, pp. 25263. http://dx.doi.org/10.1038/srep25263. PMid:27151492.

ROOZBAHANI, H., ASMAR, M., GHAEMI, N. and ISSAZADEH, K., 2014. Evaluation of antimicrobial activity of spider silk Pholcus phalangioides against two bacterial pathogens in food borne. International Journal of Advanced Biological and Biomedical Research, vol. 2, no. 7, pp. 2197-2199.

SAH, M.K. and PRAMANIK, K., 2010. Regenerated silk fibroin from $B$. mori silk cocoon for tissue engineering applications. International Journal of Environmental Sciences and Development, vol. 1, no. 5, pp. 404-408. http://dx.doi.org/10.7763/IJESD.2010. V1.78.

SARAVANAN, D. (2006). Spider silk-structure, properties and spinning. Journal of textile and apparel, technology and management, vol. 5, no. 1, pp. 1-20.

TAHIR, H. M., ZAHEER, A., \& YAQOOB, R. (2015). Antifungal potential of silk recovered from Neoscona theisi (Araneae: Araneidae). Punjab University Journal of Zoology, vol. 30, no. 2, pp. 81-83.

VARGAS, M., PASTOR, C., CHIRALT, A., MCCLEMENTS, D.J. and GONZALEZ-MARTINEZ, C., 2008. Recent advances in edible coatings for fresh and minimally processed fruits. Critical Reviews in Food Science and Nutrition, vol. 48, no. 6, pp. 496-511. http://dx.doi.org/10.1080/10408390701537344. PMid: 18568856.

ZHU, S.J., 2006. Non-chemical approaches to decay control in postharvest fruit. In: B. NOUREDDINE and NORIO S. Advances in postharvest technologies for horticultural crops. Trivandrum: Research Signpost, pp. 297-313. 